\title{
NUMERICAL STUDY ON THE COMPRESSIVE BEHAVIOUR OF AN ALUMINIUM HONEYCOMB CORE
}

\author{
NUMERIČNA ŠTUDIJA OBNAŠANJA TLAČNO OBREMENJENEGA \\ JEDRA SATOVJA IZ ZLITINE NA OSNOVI ALUMINIJA
}

\author{
Boubekeur Mohammed Bilel Mertani ${ }^{1,2}$, Boualem Keskes ${ }^{1}$, Mostapha Tarfaoui ${ }^{2}$ \\ ${ }^{1}$ Laboratory of Applied Precision Mechanics (LMPA), Institute of Optics and Precision Mechanics (IOMP), University Ferhat Abbas Sétif 1, \\ Saïd Boukhraïssa, Maabouda, 19000 Sétif, Algeria \\ ${ }^{2}$ ENSTA Bretagne, IRDL UMR CNRS 6027, 2 François Verny, 29200 Brest, France
}

Prejem rokopisa - received: 2018-02-20; sprejem za objavo - accepted for publication: 2018-11-06

doi:10.17222/mit.2018.028

\begin{abstract}
In this research, a hexagonal honeycomb core under a compressional load is studied numerically from the initial elastic regime to the fully crushed state using the Abaqus finite-element modelling. Two modelling approaches, i.e., a static analysis and an explicit non-linear analysis are applied to a 3D model of an aluminium honeycomb core. This honeycomb structure is compressed quasi statically using rigid plates and displacement control. Moreover, the crushing of the honeycomb-core structure and the failure due to buckling are verified numerically, and a study is also performed to show how different densities, cell sizes and specimen sizes can affect the average crush force and plateau force. A comparison between experimental and numerical results is drawn, showing that the numerical models can effectively predict the mean crushing force and mechanical behaviour with a good accuracy.

Keywords: sandwich structure, aluminium honeycomb core, compression load, buckling, crushing, finite-element analysis
\end{abstract}

Avtorji so raziskovali obnašanje jedra heksagonalnega satovja pod tlačno obremenitvijo. Numerična študija, izvedena s pomočjo metode končnih elementov na programskem orodju Abaqus, je potekala od začetnega elastičnega režima do popolne porušitve strukture. Uporabili so dva pristopa k modeliranju, to je: statično analizo in eksplicitno nelinearno analizo 3D modela jedra satovja iz izbrane Al zlitine (AlMg3). Izbrana struktura v obliki satovja je bila kvazi-statično tlačno obremenjena z uporabo togih plošč v režimu kontrole pomika. Nadalje so avtorji numerično verificirali porušitev strukture zaradi njene deformacije. Numerična študija je tudi pokazala, kako razlike $v$ gostoti, velikosti celic in velikosti same strukture vplivajo na povprečno in maksimalno obremenitev, ki sta potrebni za njeno porušitev. Izvedli so primerjavo med eksperimentalno dobljenimi rezultati in rezultati numeričnih simulacij. Izkazalo se je, da se dobljeni rezultati med seboj dobro ujemajo ter da lahko numerični model dokaj natančno napove povprečno obremenitev, potrebno za porušitev dane strukture.

Ključne besede: sendvič struktura, jedro satovja iz Al zlitine, tlačna obremenitev, deformacije, porušitev, numerična analiza na osnovi metode končnih elementov

\section{INTRODUCTION}

Sandwich structures with honeycomb cores are widely used in different applications such as aerospace, marine and railway engineering because of their high stiffness-to-weight ratios. Also, sandwich structures are well known because they have the ability to dissipate considerable energy generated by a large plastic deformation under compression loading. ${ }^{1,2}$

Therefore, many researchers focused their research on the mechanical behaviour of a honeycomb core, particularly in the last decade. For this reason, various experimental and numerical analyses were developed to predict the mechanical behaviour of a honeycomb core. Mechanical behaviour such as elastic response and fracture strength at a small strain under quasi-static loadings were well investigated for the honeycomb core for structural applications. ${ }^{3}$ In addition to only elastic and fracture models of the out-of-plane and in-plane crushing, ${ }^{4-6}$ transverse shearing models were also well established. ${ }^{7}$

*Corresponding author e-mail:

bkeskes@univ-setif.dz
For the case of a larger strain, theoretical, experimental and numerical studies were also reported. Theoretical models can predict the crushing pressures such as the out-of-plane crushing pressure, in-plane crushing pressure and multi-axial collapse envelope of a honeycomb using its geometrical parameters and material properties. $^{8-10}$ Other related investigations such as fracture detection using elastic waves, honeycombs with a negative Poisson's ratio, and foam-filled honeycombs were also reported in the literature. ${ }^{11-13}$

In many analytical studies, predictions of the core properties were limited to the assumptions based on regular geometry and constant mechanical properties. The approaches were mainly based on the bending deformation of inclined walls of a hexagonal unit cell that were modelled as fixed and guided end beams, while the axial deformation of the vertical walls was neglected because of its minor effect on the slender walls of a honeycomb cell. ${ }^{3,14}$ In contrast to the abundance of analytical approaches, there were very few experimental studies observing the deformation behaviour and predicting the material performance. Schwingshackl conducted 
a broad investigation of fifteen analytical approaches and proposed an alternative dynamic experimental method based on resonance response frequencies. ${ }^{15}$

Most of the work already done focused on the mechanical behaviour of a complete sandwich (face sheets or skins and a honeycomb core).

In our research, the study of the mechanical behaviour of the core of honeycomb sandwich panels subjected to uniaxial compression is conducted. Two methods of numerical modelling, the static analysis usually used in this kind of simulation and the explicit non-linear analysis originally developed to solve dynamic problems, were applied. In addition, a series of experimental investigations was conducted. A typical load-displacement curve, failure modes and effects of the cell size and specimen size on the crushing were studied. Moreover, the energy-absorption capabilities were also quantified. The results obtained were used to validate our numerical-simulation approach to different stages of the crushing of the honeycomb core.

\section{EXPERIMENTAL PART}

\subsection{Materials}

The honeycomb-sandwich cores used in this study were provided by Euro-Composites S.A. (Luxembourg); they are intended for the aircraft industry. ${ }^{16}$ The honeycomb cores were made from aluminium alloy foil 3003 H18 (AlMg3) with a density of $27.3 \mathrm{~kg} / \mathrm{m}^{3}$. The mechanical properties of the material are given in Table 3 . The tensile stress/strain curve of AA3003 H18 is shown in Figure 1. ${ }^{17}$ The curve was obtained using tensile specimens with the dimensions specified in the ASTM standard. ${ }^{18}$

The honeycomb cores consisted of open cells with densities of 55,82 and $130 \mathrm{~kg} / \mathrm{m}^{3}$. The geometrical dimensions of a specimen are shown in Table 1 . The

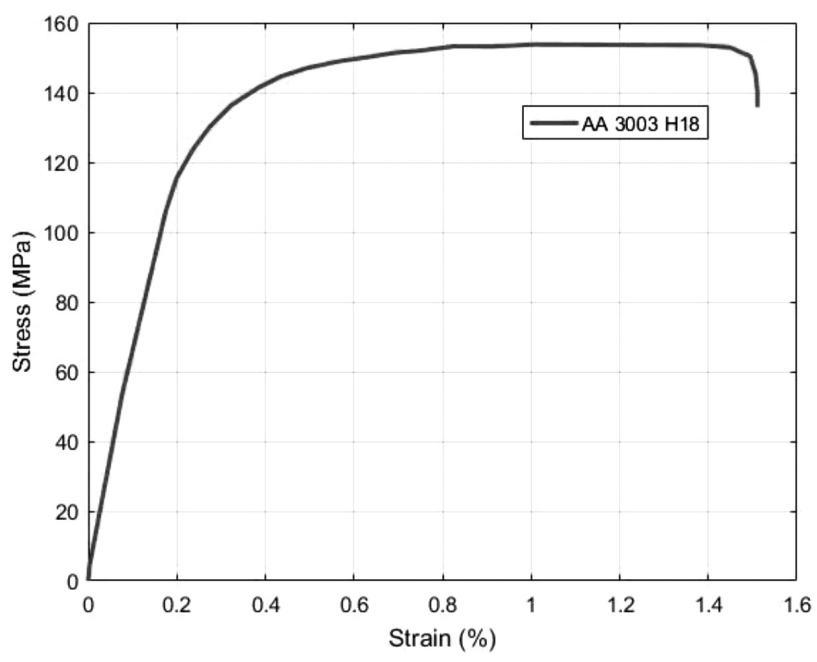

Figure 1: Engineering stress/strain curve of AA3003 H18 ${ }^{17}$ mechanical properties of the sandwich honeycomb cores are depicted in Table 2.

A series of crushing experiments were performed on aluminium honeycombs with different configurations. The specimens had cell sizes of 3.2, 6.4 and $9.6 \mathrm{~mm}$ with a wall thickness of $0.08 \mathrm{~mm}$. Different cutting sizes of the samples were used as shown in Table $\mathbf{1}$ and Figure 2. Aluminium honeycomb specimens were cut using a portable grinder without causing any damage to the honeycomb cells.

Table 1: Dimensions of the specimens in $\mathrm{mm}$

\begin{tabular}{|c|c|c|c|}
\hline Designation & ECM 3.2-130 & ECM 6.4-82 & ECM 9.6-55 \\
\hline$(\mathrm{W} \times \mathrm{L} \times \mathrm{H})$ & $30 \times 30 \times 10$ & $30 \times 30 \times 10$ & $30 \times 30 \times 10$ \\
$\mathrm{~mm}$ & $30 \times 30 \times 20$ & $30 \times 30 \times 20$ & $30 \times 30 \times 20$ \\
$40 \times 40 \times 10$ & $40 \times 40 \times 10$ & $40 \times 40 \times 10$ \\
4 & $50 \times 40 \times 20$ & $40 \times 40 \times 20$ & $40 \times 40 \times 20$ \\
& $50 \times 50 \times 10$ & $50 \times 50 \times 10$ & $50 \times 50 \times 10$ \\
& $50 \times 20$ & $50 \times 50 \times 20$ & $50 \times 50 \times 20$ \\
\hline
\end{tabular}

Table 2: Mechanical properties of honeycomb cores ${ }^{16}$

\begin{tabular}{|l|c|c|c|}
\hline \multicolumn{1}{|c|}{ Materials } & \multicolumn{3}{c|}{ Cluminium } \\
\hline \multicolumn{1}{|c|}{ Core } & 9.6 & 6.4 & 3.2 \\
\hline Size of the cell $(\mathrm{mm})$ & 55 & 82 & 130 \\
\hline Densities $\left(\mathrm{Kg} / \mathrm{m}^{3}\right)$ & 1.48 & 2.4 & 5.47 \\
\hline $\begin{array}{l}\text { Shear strength } \\
\text { (L direction) }(\mathrm{MPa})\end{array}$ & 253 & 430 & 523 \\
\hline $\begin{array}{l}\text { Shear modulus } \\
\text { (L direction) }(\mathrm{MPa})\end{array}$ & 0.88 & 1.4 & 3.36 \\
\hline $\begin{array}{l}\text { Shear strength } \\
\text { (W direction) }(\mathrm{MPa})\end{array}$ & 170 & 220 & 311 \\
\hline $\begin{array}{l}\text { Shear modulus } \\
\text { (W direction) }(\mathrm{MPa})\end{array}$ & 2.75 & 4.5 & 11.55 \\
\hline $\begin{array}{l}\text { Compressive strength } \\
\text { (MPa) }\end{array}$ & & & \\
\hline
\end{tabular}

Table 3: Mechanical properties of aluminium alloy H3003 H18

\begin{tabular}{|l|c|c|c|}
\hline \multicolumn{1}{|c|}{ Parameter } & Symbol & Unit & Value \\
\hline Young's modulus & $E$ & $\mathrm{GPa}$ & 69.0 \\
\hline Initial yield stress & $\sigma_{\mathrm{y}}$ & $\mathrm{MPa}$ & 115.8 \\
\hline Ultimate stress & $\sigma_{\mathrm{u}}$ & $\mathrm{MPa}$ & 154.5 \\
\hline Poisson's ratio & $v$ & - & 0.33 \\
\hline
\end{tabular}
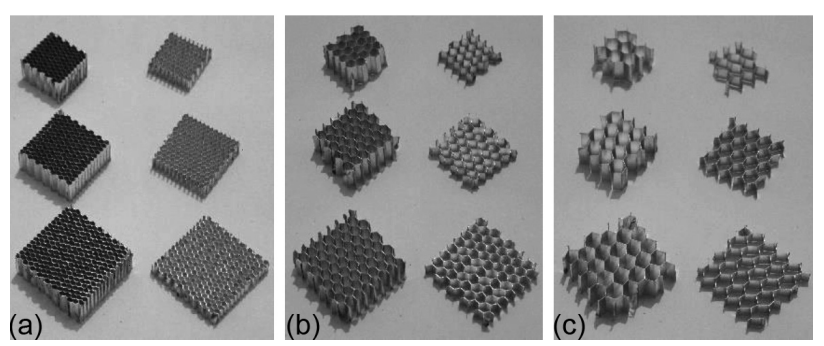

Figure 2: Aluminium honeycomb-core specimens: a) ECM 3.2-130, b) ECM 6.4-82, c) ECM 9.6-55 


\subsection{Experimental set-up}

Quasi-static tests at a constant velocity of $2 \mathrm{~mm} / \mathrm{min}$ were conducted between two flat compression test plates on the honeycomb core using an ADAMEL machine equipped with a $100-\mathrm{kN}$ load cell (Figure 3). The duration of the tests was $250 \mathrm{~s}$ for a sample with a height of $10 \mathrm{~mm}$ and $500 \mathrm{~s}$ for a sample with a height of $20 \mathrm{~mm}$. An electronic unit was used for the test control and data acquisition. A computer was used to acquire the load and displacement signals. The experimental set-up for the axial-compression test is shown in Figure 3. The test results are reported in detail in the following section.

\section{RESULTS AND DISCUSSION}

A typical load-displacement curve is shown in Figure $4 \mathbf{A}$, indicating different stages of the crushing of a honeycomb core subjected to compression. Different failure modes corresponding to the steps of the curve are illustrated in Figure 4B.

The analysis of the experimental results of the typical static-compression tests allow us to make the following statements:

- The cells buckled elastically and collapsed at a higher stress due to an inelastic action (steps 1-2 in Figures 4A and 4B).
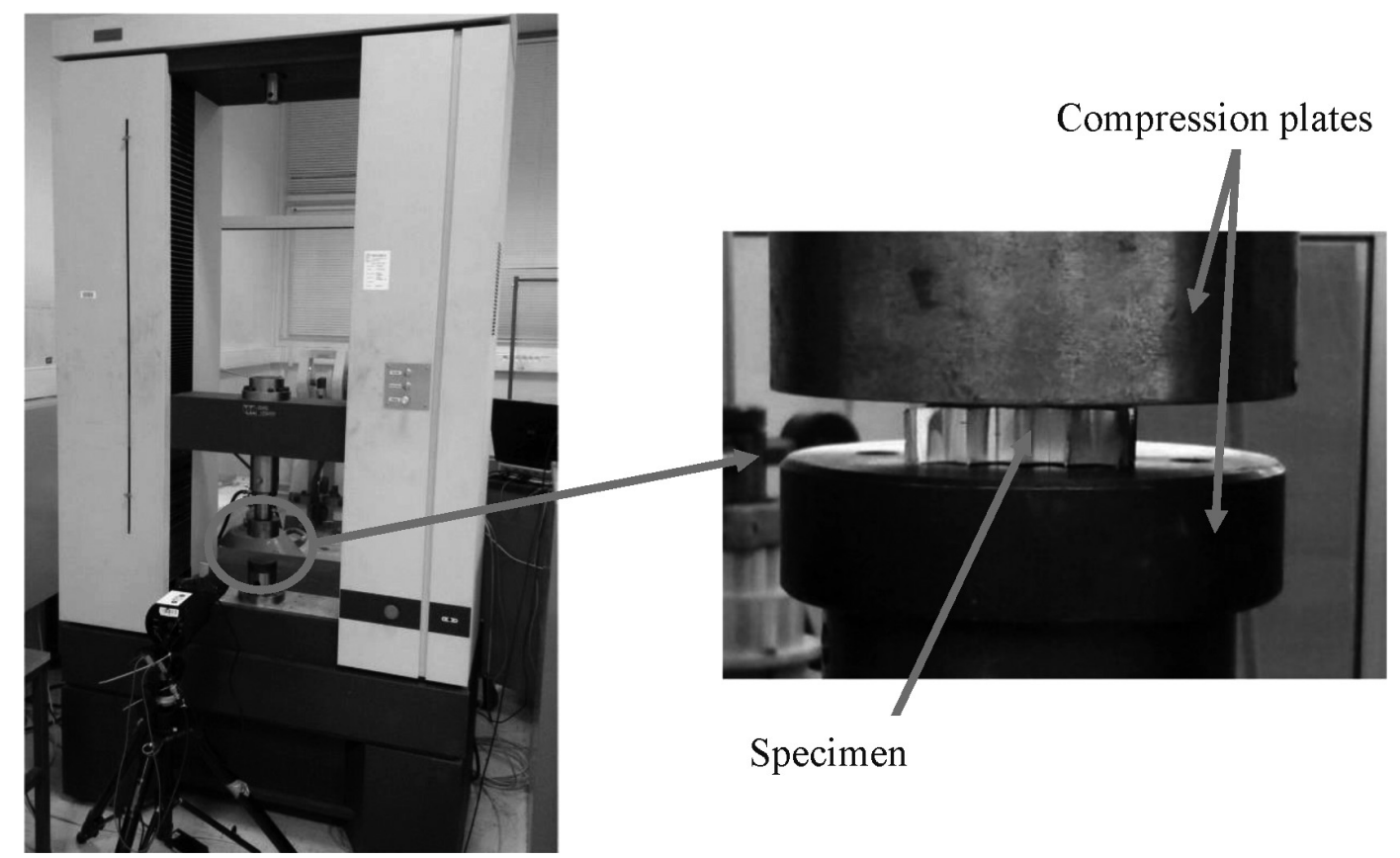

Specimen

Figure 3: Experimental set-up

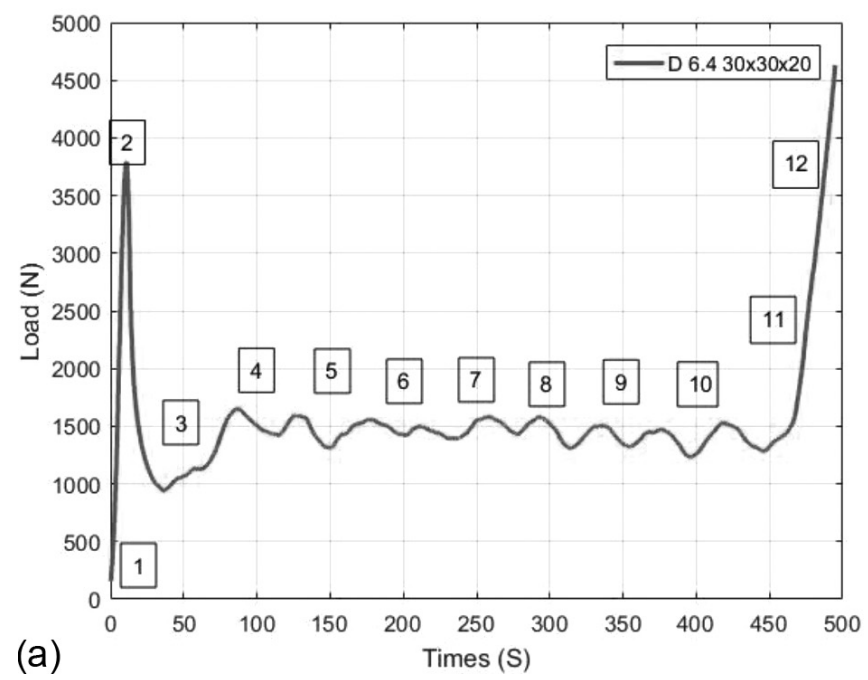

1

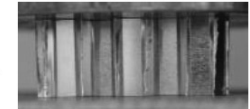

3

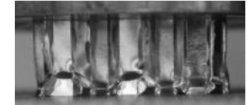

5

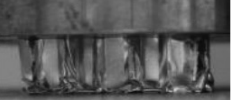

7

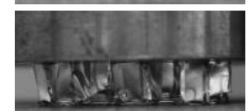

9

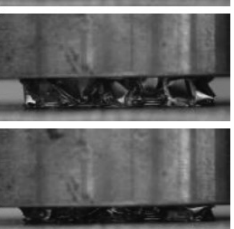

2

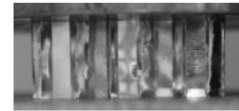

4

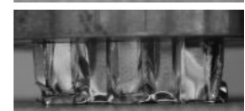

6

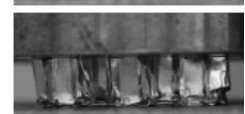

8

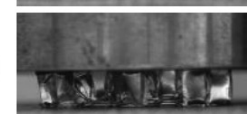

10

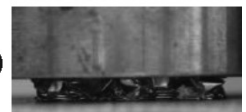

(b)

\section{2}

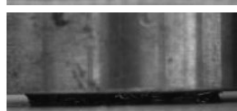

Figure 4: Typical crush process of a honeycomb core during a quasi-static axial-loading test and chronology of damage: a) typical loadingdisplacement curve, b) damage process 

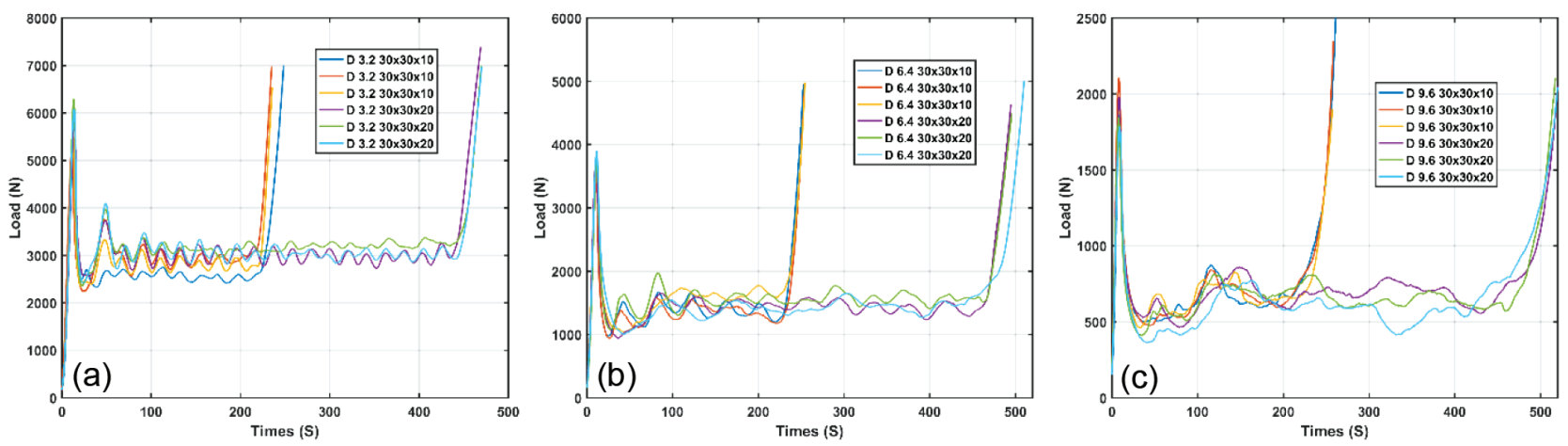

Figure 5: Force/time curves for different honeycomb cores: a) compression test for samples (D $3.230 \times 30 \times 10 \mathrm{~mm}$ and D $3.230 \times 30 \times 20$ $\mathrm{mm}$ ), b) compression test for samples (D $6.430 \times 30 \times 10 \mathrm{~mm}$ and D $6.430 \times 30 \times 20 \mathrm{~mm}$ ), c) compression test for samples $(\mathrm{D} 9.630 \times 30 \times 10$ $\mathrm{mm}$ and $\mathrm{D} 9.630 \times 30 \times 20 \mathrm{~mm}$ )

- After the first cell was crushed (steps 2-3 in Figures 4A and 4B), a progressive formation of folds was observed (steps 3-10 in Figures $\mathbf{4 A}$ and $\mathbf{4 B}$ ): this phenomenon is called the flat-plateau force.

- In the final phase of the compression test (steps 11-12 in Figures 4A and 4B), the shape of the graph shows a fast increase in the load. This explains the densification of the honeycomb core because the whole height of the panel is consumed by the folds.

Figures $\mathbf{5 A}, \mathbf{5 B}$ and $\mathbf{5 C}$ refer to group tests for all the configurations of the specimens with dimensions of $30 \times$ $30 \mathrm{~mm}$. They show that the tests performed on the samples were reproducible.

Force-displacement curves for different cell sizes are shown in Figure 6. It can be seen that the constant phase of the compression force during the test was influenced by the specimen size. The compression force was increased with the size of the sample, but the height of the sample only affected the duration of the constant phase.

The average crush force for specimens with a cell size of $3.2 \mathrm{~mm}$ and dimensions of $(30 \times 30 \times 10) \mathrm{mm}$ was $5344 \mathrm{~N}$ and the average plateau force was $3020 \mathrm{~N}$. The densification started during the deformation of the structure of $7.29 \mathrm{~mm}$. The energy absorption $\left(E_{\mathrm{a}}\right)$ in joule (J) was determined by calculating the area under the load-displacement graph using the following equation:

$$
E a=\int_{0}^{d} F(x) \mathrm{d} x
$$

where $d$ is the axial crushing distance (from $d=0$ to the start of the densification phase), $F$ is the axial crushing force and the value for the $7.29 \mathrm{~mm}$ displacement is $21.47 \mathrm{~J}$.

The force-displacement graph from Figure 6 refers to the specimens with dimensions of $(30 \times 30 \times 20) \mathrm{mm}$ and a cell size of $3.2 \mathrm{~mm}$, which were similar to the specimens with dimensions of $(30 \times 30 \times 10) \mathrm{mm}$ and a cell size of $3.2 \mathrm{~mm}$. There were three regions: the elastic region, the plateau and the densification region included in the curve. The critical force was $6061 \mathrm{~N}$ and the average plateau force was the same as before, i.e., $3020 \mathrm{~N}$.
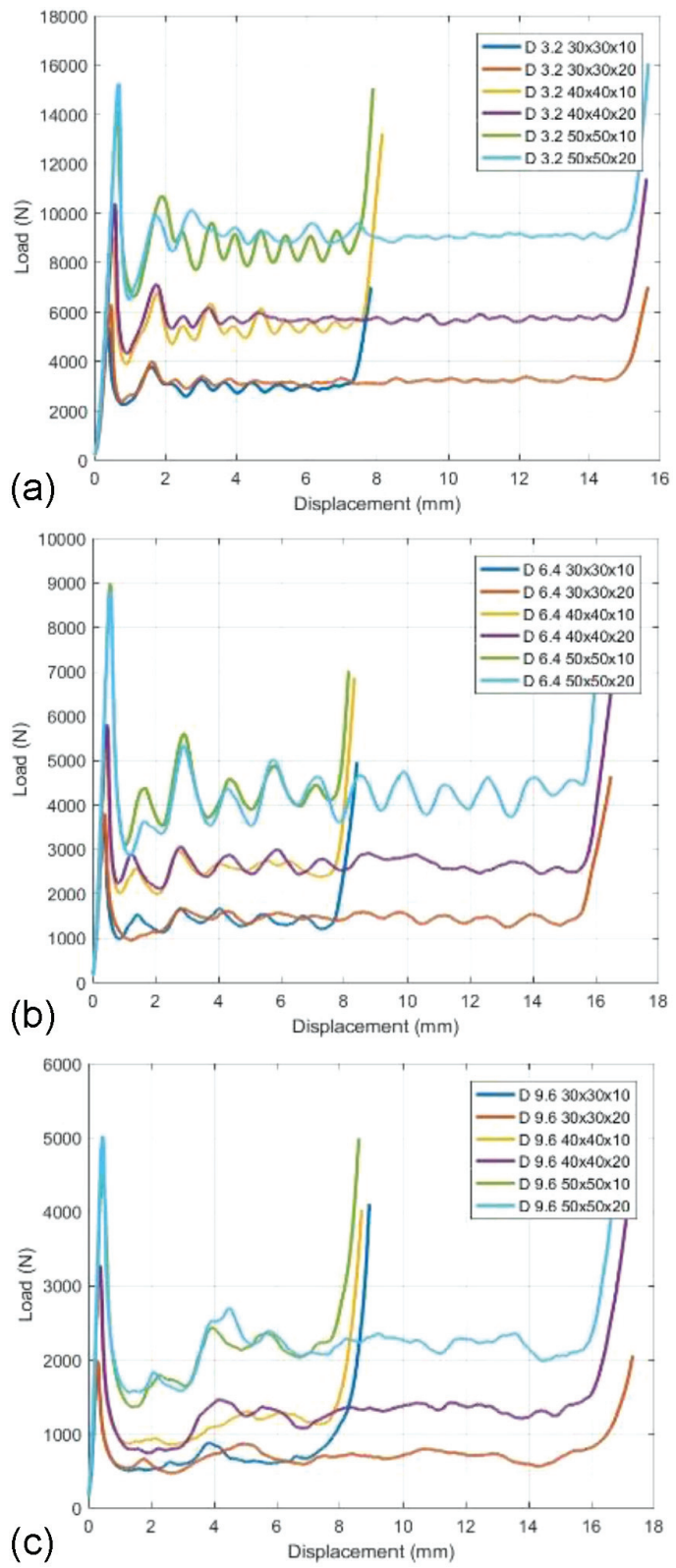

Figure 6: Force-displacement curves for honeycomb cores during the quasi-static axial-loading test: a) specimen D $3.2 \mathrm{~mm}$, b) specimen D $6.4 \mathrm{~mm}, \mathrm{c})$ specimen D $9.6 \mathrm{~mm}$ 
The densification point started at the structure deformation of $14.8 \mathrm{~mm}$ and the energy absorption was $46.81 \mathrm{~J}$.

For the other sizes of the specimens, i.e., $(40 \times 40 \times$ $(10-20)) \mathrm{mm}$ and $(50 \times 50 \times(10-20)) \mathrm{mm}$, it was found that the shape of the curve was similar to the curve of the sample with the dimensions of $(30 \times 30) \mathrm{mm}$. The results for the $(40 \times 40) \mathrm{mm}$ samples are as follows: The critical force for $H=10 \mathrm{~mm}$ is $9194 \mathrm{~N}$ and $10223 \mathrm{~N}$ for $H=20$ $\mathrm{mm}$, the average plateau force for both $H=10 \mathrm{~mm}$ and $H=20 \mathrm{~mm}$ is the same, i.e., is $5800 \mathrm{~N}$. The densification point starts at the structure deformation of $14.9 \mathrm{~mm}$ for $H=20 \mathrm{~mm}$, with an absorbed energy of $84.52 \mathrm{~J}$ and at $7.59 \mathrm{~mm}$ for $H=10 \mathrm{~mm}$ with an absorbed energy of $40.19 \mathrm{~J}$. For the $(50 \times 50) \mathrm{mm}$ sample, the results are as follows: The critical force for $H=10 \mathrm{~mm}$ is $14008 \mathrm{~N}$ and $15258 \mathrm{~N}$ for $H=20 \mathrm{~mm}$, the average plateau force for $H=10 \mathrm{~mm}$ is $9350 \mathrm{~N}$ and for $H=20 \mathrm{~mm}$ it is 9410 $\mathrm{N}$. The densification point for $H=20 \mathrm{~mm}$ starts at the structure deformation of $14.9 \mathrm{~mm}$, with an absorbed energy of $131.6 \mathrm{~J}$ and at $7.59 \mathrm{~mm}$ for $H=10 \mathrm{~mm}$, with an absorbed energy of $62.87 \mathrm{~J}$.

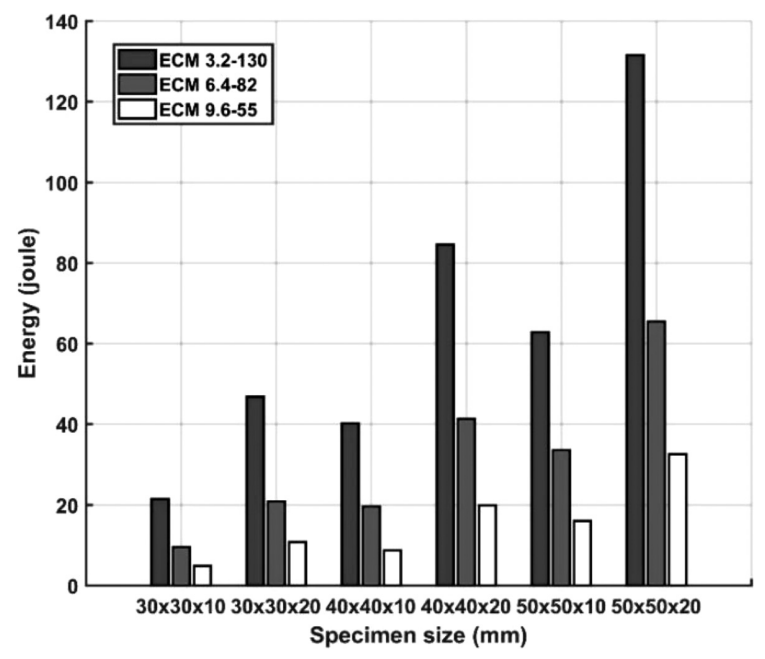

Figure 7: Absorbed-energy diagram for honeycomb cores during the quasi-static axial-compression test

Table 4: Average plateau force and absorbed energy of the honeycomb cores

\begin{tabular}{|c|c|c|c|c|c|c|}
\hline & \multicolumn{2}{|c|}{ ECM 3.2-130 } & \multicolumn{2}{|c|}{ ECM 6.4-82 } & \multicolumn{2}{|c|}{ ECM 9.6-55 } \\
\hline $\begin{array}{c}\text { Sample } \\
\text { size } \\
(\mathrm{mm})\end{array}$ & $\begin{array}{c}\text { Average } \\
\text { plateau } \\
\text { force } \\
(\mathrm{N})\end{array}$ & $\begin{array}{c}\text { Absor- } \\
\text { bed } \\
\text { energy } \\
(\mathrm{J})\end{array}$ & $\begin{array}{c}\text { Average } \\
\text { plateau } \\
\text { force } \\
(\mathrm{N})\end{array}$ & $\begin{array}{c}\text { Absor- } \\
\text { bed } \\
\text { energy } \\
(\mathrm{J})\end{array}$ & $\begin{array}{c}\text { Average } \\
\text { plateau } \\
\text { force } \\
(\mathrm{N})\end{array}$ & $\begin{array}{c}\text { Absor- } \\
\text { bed } \\
\text { energy } \\
(\mathrm{J})\end{array}$ \\
\hline $\begin{array}{c}\mathbf{3 0} \times \mathbf{3 0} \\
\times \mathbf{1 0}\end{array}$ & 3020 & 21.47 & 1430 & 9.48 & 671 & 4.88 \\
\hline $\begin{array}{c}\mathbf{3 0} \times \mathbf{3 0} \\
\times \mathbf{2 0}\end{array}$ & 3020 & 46.81 & 1460 & 20.85 & 775 & 10.79 \\
\hline $\begin{array}{c}\mathbf{4 0} \times \mathbf{4 0} \\
\times \mathbf{1 0}\end{array}$ & 5800 & 40.19 & 2550 & 19.61 & 1130 & 8.77 \\
\hline $\begin{array}{c}\mathbf{4 0} \times \mathbf{4 0} \\
\times \mathbf{2 0}\end{array}$ & 5800 & 84.52 & 2700 & 41.32 & 1300 & 19.86 \\
\hline $\begin{array}{c}\mathbf{5 0} \times \mathbf{5 0} \\
\times \mathbf{1 0}\end{array}$ & 9350 & 62.87 & 4120 & 33.52 & 2080 & 15.95 \\
\hline $\begin{array}{c}\mathbf{5 0} \times \mathbf{5 0} \\
\times \mathbf{2 0}\end{array}$ & 9410 & 131.6 & 4105 & 65.46 & 2200 & 32.61 \\
\hline
\end{tabular}

For the other cell sizes, the interpretation of the results was same as for the cell size of $3.2 \mathrm{~mm}$ and they are listed in Table 4.

Figure 7 illustrates the energy-absorption capacity of honeycomb cores and it shows that there is a close relationship between the energy-absorption capacity of a honeycomb core and the honeycomb cell size. The results presented in Table 4 and Figure 7 show a proportional increase in the energy absorbed with an increase in the specimen size and a decrease in the energy absorbed with the increasing cell size.

Table 7 presents the results of the crush force obtained during the compression tests of the honeycomb cores (Figure 6). Three tests were performed for each sample and the average value was retained. These results were then used to validate the numerical model based on the static-analysis approach.

Table 5: Average crush force for the honeycomb cores

\begin{tabular}{|c|c|c|c|c|}
\hline \multirow{2}{*}{$\begin{array}{c}\text { Sample } \\
\text { size }(\mathbf{m m})\end{array}$} & \multirow[t]{2}{*}{ Test } & $\begin{array}{c}\text { ECM } \\
3.2-130\end{array}$ & $\begin{array}{l}\text { ECM } \\
6.4-82 \\
\end{array}$ & $\begin{array}{l}\text { ECM } \\
9.6-55 \\
\end{array}$ \\
\hline & & \multicolumn{3}{|c|}{ Crush force $(\mathrm{N})$} \\
\hline \multirow{5}{*}{$\begin{array}{c}30 \times 30 \times \\
10\end{array}$} & Test\#1 & 5172 & 3554 & 1930 \\
\hline & Test\#2 & 5348 & 3505 & 2104 \\
\hline & Test\#3 & 5511 & 3629 & 1961 \\
\hline & Mean & 5344 & 3563 & 1998 \\
\hline & $\begin{array}{l}\text { Standard } \\
\text { deviation }\end{array}$ & 173 & 62 & 93 \\
\hline \multirow{5}{*}{$\begin{array}{c}30 \times 30 \times \\
20\end{array}$} & Test\#1 & 5801 & 3792 & 1981 \\
\hline & Test\#2 & 6296 & 3825 & 1842 \\
\hline & Test\#3 & 6085 & 3900 & 1787 \\
\hline & Mean & 6061 & 3839 & 1870 \\
\hline & $\begin{array}{l}\text { Standard } \\
\text { deviation }\end{array}$ & 248 & 55 & 100 \\
\hline \multirow{5}{*}{$\begin{array}{c}40 \times 40 \times \\
10\end{array}$} & Test\#1 & 9015 & 5294 & 3336 \\
\hline & Test\#2 & 8930 & 5995 & 3255 \\
\hline & Test\#3 & 9638 & 5795 & 3424 \\
\hline & Mean & 9194 & 5695 & 3338 \\
\hline & $\begin{array}{l}\text { Standard } \\
\text { deviation }\end{array}$ & 387 & 361 & 85 \\
\hline \multirow{5}{*}{$\begin{array}{c}40 \times 40 \times \\
20\end{array}$} & Test\#1 & 10373 & 7134 & 3572 \\
\hline & Test\#2 & 10159 & 5810 & 3267 \\
\hline & Test\#3 & 10136 & 6621 & 3054 \\
\hline & Mean & 10223 & 6522 & 3298 \\
\hline & $\begin{array}{l}\text { Standard } \\
\text { deviation }\end{array}$ & 131 & 668 & 260 \\
\hline \multirow{5}{*}{$\begin{array}{c}50 \times 50 \times \\
10\end{array}$} & Test\#1 & 13880 & 9833 & 4466 \\
\hline & Test\#2 & 14031 & 9861 & 4790 \\
\hline & Test\#3 & 14114 & 8957 & 4572 \\
\hline & Mean & 14008 & 9550 & 4609 \\
\hline & $\begin{array}{l}\text { Standard } \\
\text { deviation }\end{array}$ & 119 & 514 & 165 \\
\hline \multirow{5}{*}{$\begin{array}{c}50 \times 50 \times \\
20\end{array}$} & Test\#1 & 15328 & 9941 & 5018 \\
\hline & Test\#2 & 15208 & 8807 & 5046 \\
\hline & Test\#3 & 15239 & 9173 & 4859 \\
\hline & Mean & 15258 & 9307 & 4974 \\
\hline & $\begin{array}{l}\text { Standard } \\
\text { deviation }\end{array}$ & 62 & 579 & 101 \\
\hline
\end{tabular}




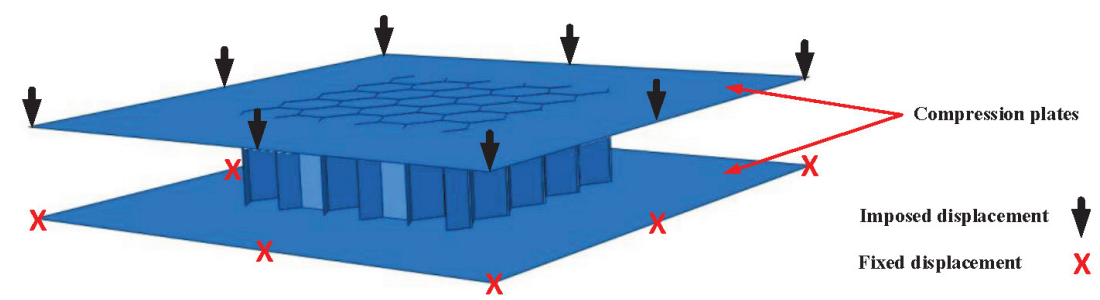

Figure 8: Boundary conditions

\section{FINITE-ELEMENT MODELLING}

As mentioned before, two modelling approaches, i.e., a static analysis and an explicit non-linear analysis were employed to study the behaviour of aluminium honeycombs in finite modelling. ABAQUS was used for the explicit non-linear finite-element code to simulate the quasi-static axial loading of aluminium honeycombs. The explicit-solution method was a true dynamic procedure originally developed to model high-speed impact events, in which inertia plays a dominant role. Therefore, in the quasi-static analysis, the goal was to model the process in the shortest time, in which inertial forces remain insignificant. To achieve a quasi-static process using an explicit dynamic procedure, the mass-scaling option was used in ABAQUS. ${ }^{19}$ The mass-scaling factor was selected so that the test time was $300 \mathrm{~s}$; in addition, this factor was chosen and tested to prove that the inertia had no influence on the test.

\subsection{Finite-element procedure}

To simulate a contact between the plates and the sample, a general contact algorithm was introduced using a penalty contact method in ABAQUS. ${ }^{19}$ Self-contact for the cellular walls of a honeycomb core was also included in the FE model, so the core walls were not allowed to fold onto themselves. The value of the coefficient of friction for the contact between the plates and the sample was chosen to be 0.15 because the flat-compression test plates are made of hardened steel and the faces of the plates were cleaned with oil to minimise the friction. This indicated friction between aluminium and steel with lubrication and the friction values in the literature were between 0.1 and 0.4 . The plates were modelled as rigid bodies using an analytical rigid technique. The initial velocity was assigned to the plate reference points and the plates were also constrained to move only in the outof-plane direction as shown in Figure 8. The honeycomb core did not have any constraint.
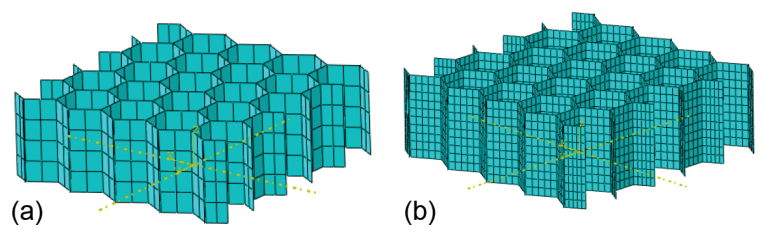

Figure 9: Mesh types for the honeycomb core: a) coarse mesh, b) convergence mesh
The mesh element selected for this model was SR4, (Figure 9) with four nodes, double-curved thick-shell elements with a reduced integration, active-stiffness hourglass control and five integration points through the cell-wall thickness. It was a robust, general-purpose element suitable for this kind of simulation. ${ }^{19}$ It had the advantage of a short computing time while maintaining a good accuracy of the results. The optimal number of the mesh was obtained after a mesh-convergence study including 5256 elements as shown in Figure 10.

\subsection{Finite-element results and discussion}

In the static analysis, the simulation was carried out until the first collapse after the elastic phase because the calculation presented many problems relating to divergence.

The deformed model obtained is shown in Figure 11B and the first crush of the cells can be observed. Figure 11A shows the FE model in the initial state before the crushing. The results obtained for the crush

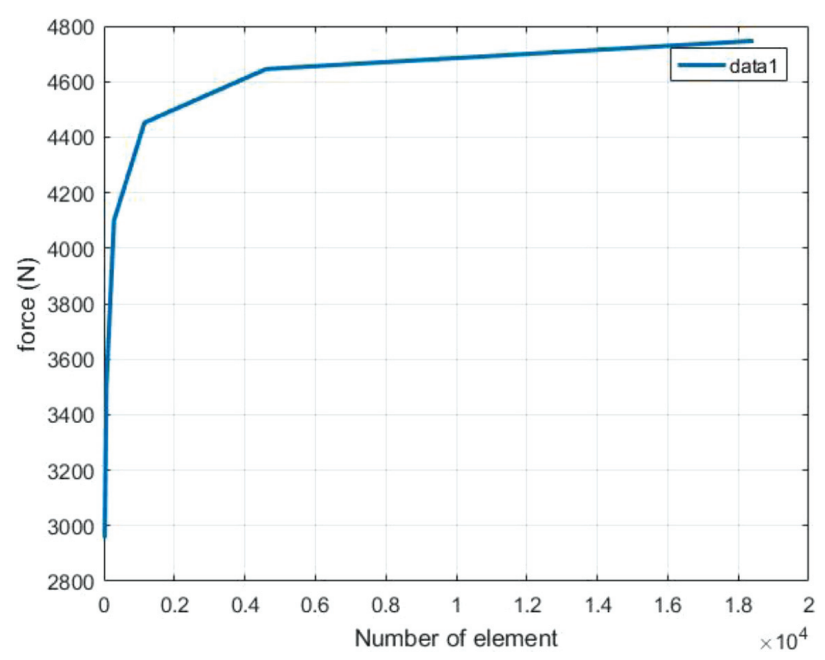

Figure 10: Mesh convergence of the honeycomb core
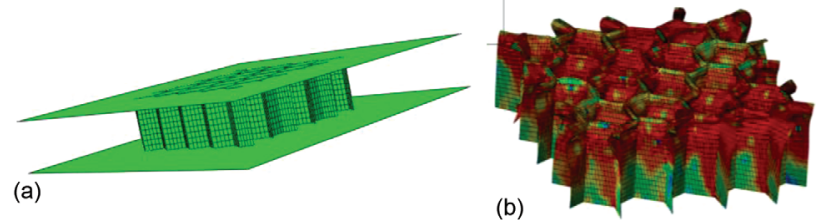

Figure 11: Results of the finite-element model: a) FE model, b) stress distribution 
Table 6: Average crush force of the honeycomb cores

\begin{tabular}{|c|c|c|c|c|c|c|c|c|c|}
\hline \multirow{2}{*}{$\begin{array}{c}\text { Specimens size } \\
(\mathbf{m m})\end{array}$} & \multicolumn{3}{|c|}{ ECM 3.2-130 } & \multicolumn{3}{c|}{ ECM 6.4-82 } & \multicolumn{3}{c|}{ ECM 9.6-55 } \\
\cline { 2 - 10 } & Test $(\mathrm{N})$ & FE $(\mathrm{N})$ & Err $(\%)$ & Test $(\mathrm{N})$ & FE $(\mathrm{N})$ & Err $(\%)$ & Test $(\mathrm{N})$ & FE $(\mathrm{N})$ & Err $(\%)$ \\
\hline $\mathbf{3 0} \times \mathbf{3 0} \times \mathbf{1 0}$ & 5178.7 & 5344 & 3.1 & 3465.5 & 3563 & 2.9 & 1888.2 & 1998 & 5.5 \\
\hline $\mathbf{3 0} \times \mathbf{3 0} \times \mathbf{2 0}$ & 5958.3 & 6061 & 1.7 & 3759 & 3839 & 2.1 & 1801.1 & 1870 & 3.7 \\
\hline $\mathbf{4 0} \times \mathbf{4 0} \times \mathbf{1 0}$ & 9304.4 & 9194 & 1.2 & 5601 & 5695 & 1.7 & 3147 & 3338 & 5.7 \\
\hline $\mathbf{4 0} \times \mathbf{4 0} \times \mathbf{2 0}$ & 10010.2 & 10223 & 2.1 & 6485 & 6522 & 0.6 & 3110.5 & 3298 & 5.7 \\
\hline $\mathbf{5 0} \times \mathbf{5 0} \times \mathbf{1 0}$ & 14792.4 & 14008 & 5.6 & 9479 & 9550 & 0.7 & 4532 & 4609 & 1.7 \\
\hline $\mathbf{5 0} \times \mathbf{5 0} \times \mathbf{2 0}$ & 14989 & 15258 & 1.8 & 9105 & 9307 & 2.2 & 4835.2 & 4974 & 2.8 \\
\hline
\end{tabular}

force are presented in Table 6 for all the specimens tested (ECM 9.6-55, ECM 6.4-82 and ECM 3.2-130). The results were in good agreement with the experimental results and showed the maximum difference of only $5.7 \%$ between the crushing forces calculated numerically and experimentally where normally this error is up to $2 \%$.

The standard explicit modelling gave good results for the first stage of the test and the force calculated with the simulation was very close to that obtained with the experimental tests.

Numerical results of the explicit non-linear analyses of specimen D $6.4 \mathrm{~mm}(30 \times 30 \times 10) \mathrm{mm}$ obtained with the finite-element model and experimental results are given in Figure 12. They show the typical stages of a quasi-static compression test of an aluminium honeycomb-core material. Three different regimes were observed: at a low strain, there are a linearly elastic region (A in Figure 12) and buckling, followed by progressive folding (B in Figure 12) and the final densification $(\mathrm{C}$ in Figure 12).

The curve obtained in Figure 12 shows that the numerical procedure was in good agreement with the experiment results, and that all the steps of the test were simulated successfully.

Figure 13 illustrates a comparison between the numerical and experimental failure behaviour where Fig-

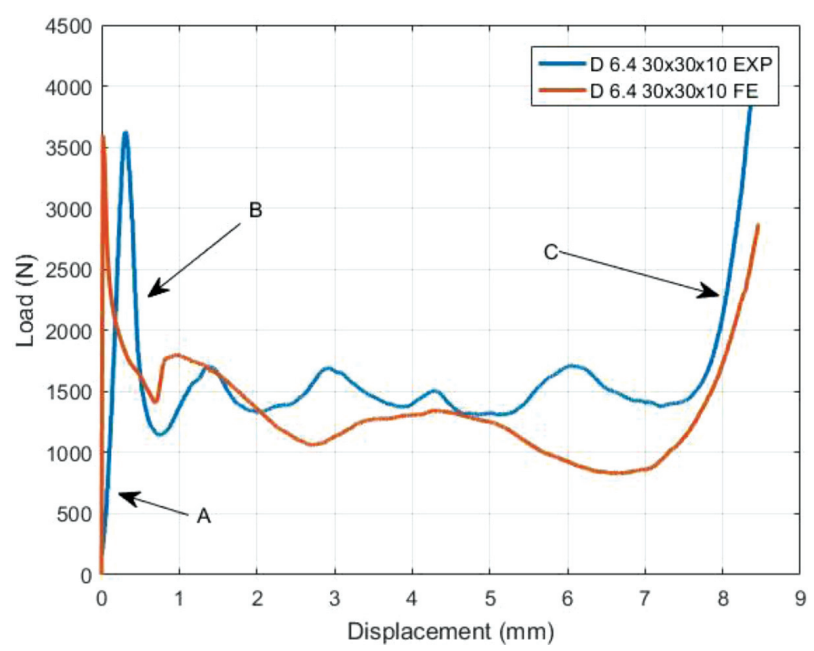

Figure 12: Comparison of the numerical and experimental load-displacement curves for $30 \times 30 \times 10 \mathrm{~mm} \mathrm{D} 6.4 \mathrm{~mm}$

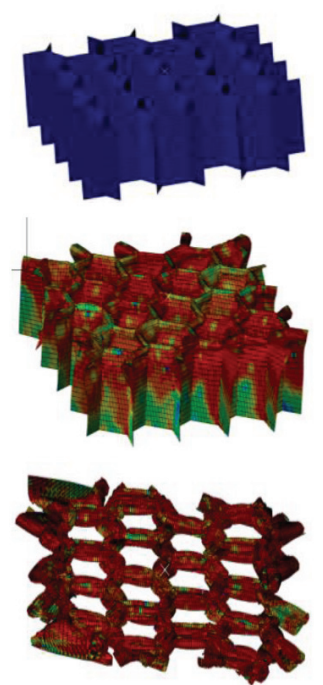

(a)

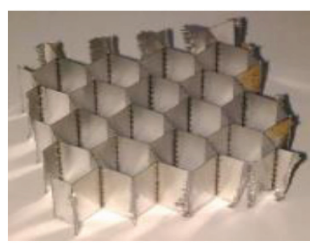

(b)

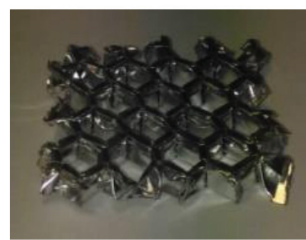

(c)

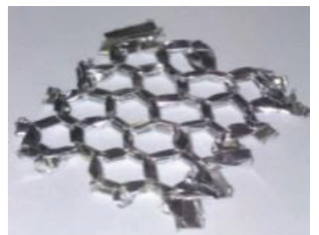

Figure 13: Visual comparison of honeycomb cores during crushing steps of FE (left) and experimental (right) investigations

ure 13a shows the numerical model and an experimental specimen before the failure and Figure 13b illustrates the damage after the first crush of cells. Figure 13c presents the final densification after the whole panel has been consumed by folds.

\section{CONCLUSIONS}

This paper focused on numerical modelling and verification of the experimental results of the crush behaviour of honeycomb cores subjected to axial compression. Two modelling approaches were employed, the static and dynamic methods. The experimental crushing resistance of honeycomb cores with various cell configurations was first determined and 18 different configurations were tested under compression. The experimental study allowed us to make the following conclusions:

- The results of the quasi-static compression tests show that the crush response consists of three phases: at low strains, there are a linearly elastic region and buckling, followed by progressive folding and the final densification.

- The crushing force is influenced by the specimen size. It increases with the size of the sample, but the 
height of the sample only affects the duration of the constant phase.

- The energy absorption is strongly influenced by the cell diameter; it increases with a decreasing diameter. The height of a honeycomb core plays a very important role in the energy-absorption process and these two quantities are found to be directly proportional.

Regarding the numerical study, we can make the following conclusions:

- It is demonstrated that the Abaqus static modelling gives good results for the first-stage failure of the compression test, but it is unable to reproduce the rest of the failure taking place during the test. This modelling approach allows us to find the value of the crushing force for all the configurations of the honeycomb cores. The numerical results are in good agreement with the experimental results.

- The dynamic modelling technique is successful at reproducing all the steps of the compression test and this method gives a good correlation with the experimental compression tests for aluminium honeycombs. The inconvenience of this method is the fact that it requires greater computing resources.

- Different failure modes of the honeycomb crash process obtained with the FE modelling have the same shapes as those of the experimental failure modes, showing all the stages of the crushing process.

\section{Acknowledgements}

The authors gratefully acknowledge the Algerian and French state for the financial support of this work in the framework of program PROFAS B+ 2015-2016.

\section{REFERENCES}

${ }^{1}$ O. A. Ganilova, J. J. Low, Application of smart honeycomb structures for automotive passive safety, Proceedings of the Institution of Mechanical Engineers, Part D: Journal of Automobile Engineering, 232 (2018) 6, 797-811, doi:10.1177/0954407017708916

${ }^{2}$ G. Lu, T. Yu, Energy absorption of structures and materials, $1^{\text {st }}$ ed., Elsevier, 2003, 268-316

${ }^{3}$ L. J. Gibson, M. F. Ashby, Cellular solids: Structure and properties, $2^{\text {nd }}$ ed., Cambridge University Press, Cambridge 1999
${ }^{4}$ J. Zhang, M. F. Ashby, The out-of-plane properties of honeycombs, International Journal of Mechanical Sciences, 34 (1992) 6, 475-489, doi:10.1016/0020-7403(92)90013-7

${ }^{5}$ J. Zhang, M. F. Ashby, Buckling of honeycombs under in-plane biaxial stresses, International Journal of Mechanical Sciences, 34 (1992) 6, 491-509, doi:10.1016/0020-7403(92)90014-8

${ }^{6}$ W. Zhao, Z. Xie, X. Li, X. Yue, J. Sun, Compression after impact behaviour of titanium honeycomb sandwich structures, Journal of Sandwich Structures \& Materials, 00 (2017) 0, 1-19, doi:10.1177/ 1099636217707150

${ }^{7}$ G. Shi, P. Tong, Equivalent transverse shear stiffness of honeycomb cores, International journal of solids and structures, 32 (1995) 10 , 1383-1393, doi:10.1016/0020-7683(94)00202-8

${ }^{8}$ T. Wierzbicki, Crushing analysis of metal honeycombs, International Journal of Impact Engineering, 1 (1983) 2, 157-174, doi:10.1016/ 0734-743X(83)90004-0

${ }^{9}$ J. W. Klintworth, W. J. Stronge, Elasto-plastic yield limits and deformation laws for transversely crushed honeycombs, International Journal of Mechanical Sciences, 30 (1988) 3, 273-292, doi:10.1016/ 0020-7403(88)90060-4

${ }^{10}$ D. Mohr, M. Doyoyo, Experimental investigation on the plasticity of hexagonal aluminum honeycomb under multiaxial loading, Journal of Applied Mechanics, 71 (2004) 3, 375-385, doi:10.1115/ 1.1683715

${ }^{11} \mathrm{~S}$. Thwaites, N. H. Clark, Non-destructive testing of honeycomb sandwich structures using elastic waves, Journal of Sound and Vibration, 187 (1995) 2, 253-269, doi:10.1006/jsvi.1995.0519

${ }^{12}$ D. Prall, R. S. Lakes, Properties of a chiral honeycomb with a poisson's ratio of -1 , International Journal of Mechanical Sciences, 39 (1997) 3, 305-314, doi:10.1016/S0020-7403(96)00025-2

${ }^{13} \mathrm{C}$. Wu, C. Weeks, C. Sun, Improving honeycomb-core sandwich structures for impact resistance, Journal of Advanced Materials, 26 (1995) 4, 41-47

${ }^{14}$ I. Masters, K. Evans, Models for the elastic deformation of honeycombs, Composite Structures, 35 (1996) 4, 403-422, doi:10.1016/ s0263-8223(96)00054-2

${ }^{15}$ C. W. Schwingshackl, G. S. Aglietti, P. R. Cunningham, Determination of honeycomb material properties: Existing theories and an alternative dynamic approach, Journal of Aerospace Engineering, 19 (2006) 3, 177-183, doi:10.1061/(ASCE)0893-1321(2006)19:3(177)

${ }^{16}$ ECM-Honeycomb Data Sheet, Euro Composites S.A., Luxembourg 2015

${ }^{17}$ X. Zhang, H. Zhang, Z. Wen, Experimental and numerical studies on the crush resistance of aluminium honeycombs with various cell configurations, International Journal of Impact Engineering, 66 (2014), 48-59, doi:10.1016/j.ijimpeng.2013.12.009

${ }^{18}$ ASTM E8 / E8M-16a:2016, Standard Test Methods for Tension Testing of Metallic Materials, ASTM International, West Conshohocken

${ }^{19}$ Abaqus, Ver 6.14, Dassault Systemes Simulia Corporation, Rhode Island 2014 